\title{
Management of agro-tourism case study (Parashar agro - tourism)
}

\author{
V. B. GHOLAP, S. R. BENKE AND P. V. GADE
}

Received : 17.06.2016; Revised : 15.08.2016; Accepted : 02.09.2016

\begin{abstract}
Agro tourism is complimentary to traditional agricultural activities. It is an opportunity for farmers to use the available resources in a diversified and innovative way. It creates a win -win situation to farmers as well as tourists. Farmers earn better from innovative use of available resources and the tourist can enjoy village life and nature in an affordable prices. Not only are those, the villages also benefited due to the development of agro-tourism. Some cases of agro-tourism in Maharashtra dist. Raigad; Pune and Satara have proved that agro-tourism not only bring development of farmers but to the village as a whole from social and economic angle. Maharashtra is the third largest state in India, both in area and population. It is bestowed with $720 \mathrm{~km}$ long coastline. It is nestled in the Western Ghats and Sahyadri mountain ranges and with semievergreen and deciduous forests. Maharashtra is one of the major tourist centres in the India and there is large scope and great potential to develop agro-tourism. The scope of the study is limited to identify the satisfaction level and motivating factors for visiting agro-tourism. The present study was conducted on the Parasher agro-tourism at post Rajuri Taluka Junner district Pune is based on primary data. A sample of 60 visitors is selected at random to know their preferences to Parasher Agro- tourism. The primary data were collected through a direct interview schedule through a well designed questionnaire. In addition to this, Garrett's ranking technique was used to provide a rank order with respect to the important factors to participate agro-tourism. The result of the study showed that majority of respondents visited the agro-tourism to taste local cuisine, mental and physical relaxation, close to nature, escape from stress, to be together with family and friends, to experiencing agricultural life and an escape from city life. Being closer to nature factor received the highest mean score of 57.13. It proves that the being closer to nature factor was considered as the most important factor influencing the respondents' decision to visit an agro-tourism. Experiencing rural culture got the second rank with a mean score of 51.61, which proves that the urban people be in love with rural culture; farm stay got the third rank with mean score of 50.06. Other important factors are natural greenery, participating in farm activities and authentic rural hospitality in agro-tourism.
\end{abstract}

KEY WORDS : Agriculture, Agro -tourism, Rural tourism, Visitors attitude

How to cite this paper : Gholap, V.B., Benke, S.R. and Gade, P.V. (2016). Management of agro-tourism case study (Parashar agrotourism). Internat. J. Com. \& Bus. Manage, 9(2) : 128-133. DOI: 10.15740/HAS/IJCBM/9.2/128-133.

Correspondence to:

V.B. GHOLAP, Department of Agri-Business Management, Padmashree Dr. D. Y. Patil College of Agriculture Business Management, Akurdi, PUNE (M.S.) INDIA

Authors' affiliations:

S. R. BENKE, Department of Agricultural Economics, Padmashree Dr. D. Y. Patil College of Agriculture Business Management, Akurdi, PUNE (M.S.) INDIA
P. V. GADE, Department of Agri-Business Management, Padmashree Dr. D. Y. Patil College of Agriculture Business Management, Akurdi, PUNE (M.S.) INDIA 